\title{
REVITALISASI PENDIDIKAN KARAKTER SEBAGAI UPAYA PENEGUHAN KESADARAN NASIONAL PADA SISWA SMAN 01 BATU
}

\author{
Fiky Inmandari', Nurbani Yusuf ${ }^{2}$, Trisakti Handayani ${ }^{3}$ \\ ${ }_{1,2,3}$ FKIP Universitas Muhammadiyah Malang, Indonesia \\ Email: fikyinmandari@gmail.com \\ Email: nurbani@umm.ac.id \\ Email: trisakti@umm.ac.id
}

\begin{abstract}
ABSTRAK
Penelitian ini bertujuan untuk (1) menjelaskan penerapan pendidikan karakter di SMA Negeri 01 Kota Batu, (2) menjelaskan kendala yang dihadapi dalam proses penerapannya, (3) menganalisis revitalisasi yang dilakukan sebagai upaya peneguhan kesadaran nasional pada siswa. Penelitian dilakukan menggunakan metode penelitian kualitatif, dengan subjek penelitian yaitu, guru PPKn, Waka Kesiswaan, dan siswa. Pengumpulan data dilakukan dengan melakukan observasi, dokumentasi, dan wawancara secara langsung terhadap informan. Data dianalisis melalui tahap pengumpulan data, penyajian data dan penarikan kesimpulan. Pemeriksaan keabsahan data dilaksanakan dengan teknik triangulasi metode hasil yang diperoleh dalam penelitian yakni, (1) penerapan pendidikan karakter melalui pembelajaran dikelas, sosialisasi, dan skegiatan ekstrakulikuler maupun intrakulikuler (2) kendala adanya ketidaksinergian antara nilai-nilai yang diterapkan disekolah dengan nilainilai yang dierapkan diluar sekolah (3) revitalisasi berjalan konstan dan konsisten, tidak hanya melalui pembelajaran, dan sosialisasi tetapi juga melalui prakter secara langsung.
\end{abstract}

Kata Kunci: Pendidikan Karakte; Kesadaran Nasional; Revitalisasi.

\section{ABSTRACT}

This study aims to (1) explain the application of character education in State High School 01 Batu, (2) explain the obstacles encountered in the process of its application, (3) analyze the revitalization done as an effort to strengthen national awareness of students. The study was conducted using qualitative research methods, with research subjects is, PPKn teachers, head of student affairs, and students. Data collection is done by conducting observations, documentation, and interviews directly with informants. Data were analyzed through the stages of data collection, data presentation and drawing conclusions. Checking the validity of the data is carried out by the triangulation technique of the results obtained in the research is, (1) the application of character education through classroom learning, socialization, and extracurricular and intraculsive activities (2) the constraints of the disinergence between the values applied in schools and the values applied outside of school (3) revitalization is constant and consistent, not only through learning and socialization but also through practical practice.

Keywords: Character Education; National Awareness; Revitalization.

\section{PENDAHULUAN}

Penerapan pendidikan yang semakin dikembangkan di Indonesia pada saat ini merupakan bentuk berkembangnya pendidikan di Indonesia. Sistem pendidikan dan kompetensi guru menjadi penentu pokok perkembangan pendidikan di Indonesia.
Pendidikan karakter demi merubah bangsa menjadi lebih bermartabat sejalan dengan memudarnya karakter cinta tanah air anak bangsa. Yaumi (2015) berpendapat bahwa, hanya dengan pendidikanlah seluruh potensi yang dimiliki manusia berkembang sehingga menjadi manusia seutuhnya. 
Undang-Undang Republik Indonesia nomor:20tahun2003tentangSistemPendidikan Nasional (UU Sisdiknas) merumuskan fungsi dan tujuan pendidikan nasional yang harus digunakan dalam mengembangkan upaya pendidikan di Indonesia. Pasal 3 UU Sisdiknas menyebutkan, "Pendidikan nasional berfungsi mengembangkan dan membentuk watak serta peradaban bangsa yang bermartabat dalam rangka mencerdaskan kehidupan bangsa, bertujuan untuk berkembangnya potensi peserta didik agar menjadi manusia yang beriman dan bertakwa kepada Tuhan Yang Maha Esa, berakhlak mulia, sehat, berilmu, cakap, kreatif, mandiri, dan menjadi warga negara yang demokratis serta bertanggungjawab. Berbagai macam cara tersebut dilakukan dalam dunia pendidikan melalui beberapa metode seperti memasukan budaya lokal kedalam pembelajaran demi terciptanya pengetahuan mengenai budaya Indonesia yang sebenaranya dan menumbuhkan rasa cinta terhadap tanah air serta menggerakan kembali melalui mata pelajaran PPKn (Pendidikan Pancasila dan Kewarganegaraan ).

Upaya peningkatan mutu pendidikan nilai dan pendidikan kewarganegaraan, diperlukan suatu strategi atau pola pendekatan yang tepat dalam proses belajar mengajar disekolah salah satunya yakni pendekatan belajar bebas, pendekatan belajar tuntas, pendekatan saintifik, dan pendekatan sikap guru. Berbagai pendekatan tersebut diharapkan mampu untuk memfasilitasi penanaman konsep dasar pendidikan nilai dan pendidikan kewarganegaraan. Sehingga dapat mencetak alumni pendidikan yang unggul, yakni para anak bangsa yang beriman, bertaqwa, beakhlak mulia, mempunyai keahlian dibidangnya, dan berkarakter, (Sutrisno, 2016).

Wacana nasionalisme dalam kehidupan berbangsa dan bernegara diera globalisasi ini memiliki daya tarik karena sekarang kobaran semangat nasionalisme generasi muda mulai luntur. Lunturnya nasionalisme bangsa dapat menjadi kecaman terhadap terkikisnya nilai-nilai patriotism yang menjadi landasan kecintaan terhadap bumi pertiwi. Keruntuhan suatu bangsa ditandai dengan semakin runtuhnya tata nilai dan karakter suatu bangsa, karakter dan mentalitas rakyat yang kokoh dari suatu bangsa tidak terbentuk secara alami, melainkan melalui interaksi sosial yag dinamis dan serangkaian program yang diarahkan oleh pemimpin bangsa.

Pendidikan merupakan kebutuhan untuk kehidupan yang manusiawi. Menurut Undang Undang No. 20 Tahun 2003 tentang Sistem Pendidikan Nasional pasal 1 ayat 1 menyebut bahwa, pendidikan adalah usaha sadar dan terencana untuk mewujudkan suasana belajar dan proses pembelajaran agar peserta didik secara aktif mengembangkan potensi dirinyauntuk memiliki kekuatan spiritual keagamaan, pengendalian diri, kepribadian, kecerdasan, akhlak mulia serta keterampilan yang diperlukan dirinya, masyarakat, bangsa, dan Negara. Melalui pendidikan dan kesadaran pentingnya pendidikan manusia diharapkan memiliki sikap dan perilaku yang berbudi sesuai dengan norma-norma dan nilai yang berlaku. Melalui pendidikan, manusia dapat mendewasakan dirinya agar mampu membedakan mana yang baik dan mana yang kurang baik. Hal tersebut dikuatkan pula oleh Bapak Pendidikan Nasional Indonesia yaitu Ki Hajar Dewantara, pendidikan yaitu tuntutan didalam hidup tumbuhnya anak-anak, adapun maksudnya, pendidikan yaitu menuntun segala kodrat yang ada pada anak-anak itu, agar mereka sebagai manusia dan sebagai anggota masyarakat dapatlah mencapai keselamatan dan kebahagiaan setinggi-tingginya.

Menurut Ilahi (2014), Indonesia merupakan Negara yang mengalami kegagalan implementasi pendidikan karakter. Bahkan, implementasi dan hasil yang dicapai tidak sesuai dengan yang dirahapkan, sehingga perlu untuk dipertanyakan ulang 
mengenai kelemahan-kelemahan yang mesti diperbaiki dan dibenahi secara berkelanjutan. Beliau juga berpendapat bahwa, penerapan pendidikan karakter yang diajarkan mengalami pergeseran paradigma (shifting paradigm) dari nilainilai luhur bangsa menjadi nilai-nilai egosentris yang melekat pada individu generasi muda. Berdasarkan data KPAI ( Komisi Perlindungan Anak Indonesia ) ditulis oleh Firmansyah \& Anwar (2018), mencatat kasus tawuran di Indonesia meningkat 1,1\% sepanjang tahun 2018. Hasil wawancara dari metro.tempo.co dengan Komisioner Bidang Pendidikan KPAI yaitu, ibu Retno Listiyarti, pada Rabu, 12 September 2018 mengatakan, tahun lalu angka kasus tawuran hanya 12,9 persen, tetapi pada tahun ini menjadi 14\% presentasenya. Hal tersebut membuktikan bahwa semakin lemahnya kesadaran nasional generasi muda saat ini.

Pada dasarnya sekolah seharusnya merupakan suatu lembaga atau lingkungan yang membantu tercapainnya cita-cita keluarga dan masyarakat. Jadi, lingkungan keluarga dan sekolah merupakan lingkungan yang banyak menentukan perkembangan peserta didik. Lingkungan masyarakat merupakan lembaga pendidikan ketiga setelah keluarga dan sekolah. Pendidikan dalam masyarakat dapat dikatakan pendidikan secara tidak langsung, pendidikan yang dilaksanakan secara tidak sadar oleh masyarakat, (Saat, 2015).

Terkait dengan objek penelitian yang dilakukan, yaitu di SMA Negeri 01 Kota Batu, hal ini dikarenakan secara akademik sekolah tersebut dinobatkan sebagai sekolah dengan lulusan terbaik di Kota Batu. Dibuktikan dengan penerapan disiplin di sekolah tidak hanya untuk siswa tetapi juga untuk guru. Hal itu diterapkan demi terciptanya kerjasama dalam membangun, memelihara dam memperbaiki aturanaturan dan norma-norma. Sebagai contoh salah satu kegiatan yang baru baru saja dilaksanakan oleh sekolah guna menerapkan pendidikan karakter bangsa bagi siswa adalah kegiatan Latihan Dasar Kepemimpinan dan Manajemen Siswa (LDKSM). Terlihat sebagai sekolah negeri rujukan di Kota Batu, SMA Negeri 1 Kota Batu memiliki visi dan misi sekolah yang mendukung terciptanya pendidikan karakter sebagai upaya peneguhan kesadaran nasional siswa.

Berdasarkan hal tersebut diatas tujuan dari penelitian ini adalah, (1) Untuk menjelaskan pelaksanaan pendidikan karakter yang telah diupayakan di SMANegeri 01 Kota Batu, (2) Untuk menjelaskan faktor kendala yang dihadapi dalam penerapan pendidikan karakter sebagai upaya semakin teguhnya kesadaran nasional siswa di SMA Negeri 01 Kota Batu, (3) Untuk menganalisis revitalisasi pada penguatan pendidikan karakter yang dapat dilakukan sebagai upaya peneguhan kesadaran nasional generasi muda demi terciptanya keteguhan rasa nasionalisme

Revitalisasi secara etimologis bermakna 'proses penghidupan kembali'. pengertian revitalisasi ini secara umum adalah usaha-usaha untuk menjadikan sesuatu itu menjadi penting dan perlu sekali. Pendidikan Karakter adalah usaha sadar dan terencana untuk mewujudkan suasana serta proses pemberdayaan potensi dan pembudayaan peserta didik guna membangun karakter pribadi atau kelompok yang unik baik sebagai warga Negara. Karakter dimaknai sebagai cara berpikir dan berperilaku yangkhas tiap individu untuk hidup dan bekerja sama, baik dalam lingkup keluarga, masyarakat, bangsa, dan negara. Kesadaran Nasional adalah suatu sikap yang dimiliki suatu bangsa berkaitan dengan tanggung jawab hak dan kewajiban. Kesadaran Nasional atau yang disebut juga nasionalisme dalam bahasa belanda "Natie" atau dalam bahasa inggris "nation" yang berarti bangsa.

Lima nilai utama karakter yang saling berkaitan membentuk jejaring nilai yang perlu dikembangkan sebagai prioritas 
Gerakan PPK. Nilai sebagaimana yang dimaksud pada Permendikbud Nomor 20 Tahun 2018 pada pasal 2 yaitu religiusitas, nasionalisme, kemandirian, gotong royong, dan integritas yang terintegrasi dalam kurikulum.Upaya dalam menghidupkan dan membangkitkan kembali (Revitalisasi) pendidikan karakter yang merupakan langkah penting dilakukan oleh pemerintah seperti dengan mengintegrasikan nilainilai karakter ke dalam berbagai kurikulum yang ada di sekolah-sekolah mulai dari tingkat rendah sampai tingkat tinggi.

Penelitian yang relevan menyebutkan pula bahwa, revitalisasi pendidikan karakter harus dilakukan secara menyeluruh, karena dengan berkembangnya berbagai isu-isu, Indonesia dianggap belum mampu membangun karakter bangsa. Pendekatan menyeluruh dalam pendidikan karakter adalah cara pandang, bahwa untuk membangun karakter perlu dikembangkan sebuah sistem pendidikan karakter yang memungkinkan seluruh unsur-unsur karakter (ngerti, ngroso, dan nglakoni) atau unsur-unsur (moral knowing, moral feeling, dan moral action) atau keseimbangan pikir, dzikir, ikhtiar dapat dipraktekkan dalam kehidupan dan pembelajaran nilai dan karakter di institusi pendidikan. Pendidikan karakter merupakan suatu hal yang beradab dan bermartabat, baik di mata Tuhan, dunia Internasional, dan manusia (Setiawati, 2017)

Hal tersebut sejalan dengan yang telah dilakukan di SMA Negeri 01 Kota Batu, upaya yang dilakukan untuk revitalisasi pendidikan karakter demi terciptanya keteguhan kesadaran nasional, tidak hanya melalui sosialisasi dan pembelajaran, tetapi juga melalui praktek dalam berbagai pembiasaan di sekolah. Sehingga siswa tidak hanya mengerti dan mengetahui, tetapi langsung menjalankan dan melaksanakan mempraktekan dalam kegiatan sehari-hari di sekolah.

Penelitian oleh Muqoyyidin (2014) menyebutkan bahwa, Pelaksanaan pendidikan karakter dalam konteks makro kehidupan berbangsa dan bernegara Indonesia, merupakan komitmen seluruh sektor kehidupan, bukan hanya sektor pendidikan nasional. Keterlibatan aktif dari sektor-sektor pemerintahan lainnya, khususnya sektor keagamaan, kesejahteraan, pemerintahan, komunikasi dan informasi, kesehatan, hukum dan hak asasi manusia, serta pemuda dan olahraga juga sangat dimungkinkan. Dalam revitalisasi jati diri bangsa melalui pendidikan karakter, strategi mikro dalam pendidikan karakter, dapat dilakukan melalui keluarga, keluarga dapat berperan sebagi fondasi.

Berdasarkan hasil temuan oleh Lestari (2019), terdapathal-hal yang dapat dilakukan untuk menumbuhkan rasa nasionalisme generasi muda yaitu, memberikan contoh dan tindakan yang baik tentang rasa menghormati dan mencintai bangsa dan negara dengan cara mengenang perjuangan-perjuangan para pahlawan bagi kemerdekaan, memberikan pengawasan kepada anak untuk memastikan tumbuh kembang anak berjalan dengan baik dalam lingkup yang kondusif, menggunakan produk-produk dalam negeri serta melestarikan kebudyaan yang ada di dalam negeri sendiri agar tidak dilupakan oleh generasi penerus bangsa, menghilangkan pemikiran etnosentrisme dalam masyarakat karenabangsa Indonesia adalah bangsa yang multikultural dan harus selalu dapat menerima perbedaan yang ada, selektif dalam menyaring kebudayaan-kebudayaan asing yang masuk kedalam negeri yang dilakukan sesuai dengan penerapan nilainilai Pancasila.

\section{METODE}

Metode yang digunakan dalam penelitian ini adalah pendekatan kualitatif, mengkaji perspektif partisipan dengan strategi-strategi yang bersifat interaktif dan fleksibel. Penelitian kualitatif ditujukan untuk memahami fenomena-fenomena sosial dari sudut pandang partisipan. 
Pendekatan Kualitatif menekankan pada pembangunan naratif atau deskripsi tekstual atas fenomena yang diteliti. Ringkasan perbedaan kedua pendekatan penelitian ini adalah penelitian deskriptif menggambarkan perilaku, pemikiran, atau perasaan suatu kelompok atau individu. Contoh umum dari penelitian deskriptif adalah jajak pendapat, yang menggambarkan sikap suatu kelompok orang. Penelitian deskriptif, peneliti kecil upayanya untuk menghubungkan perilaku yang ditelitidengan variabellainnyaataupun menguji atau menjelaskan penyebab sistematisnya. Seperti namanya, penelitian deskriptif hanya mendeskripsikan.

Metode ini digunakan untuk mengetahui sejauh mana pelaksanaan penerapan pendidikan karakter di SMA Negeri 01 Kota Batu. Sebagai metode untuk memperoleh data yang konkrit mengenai pelaksanaan revitalisasi pendidikan karakter dan melihat secara langsung tingkat kesadaran nasional dari penerapan-penerapan yang dilakukan sekolah.

Menurut Sugiyono (2015) teknik pengumpulan data merupakan langkah yang paling strategis dalam penelitian, karena tujuan dari penelitian adalah mendapatkan data. Teknik pengumpulan data yang digunakan untuk memperoleh data mengenai penguatan pendidikan karaktersebagai upaya peneguhan kesadaran nasional siswa di SMA Negeri 01 Kota Batu yang meliputi, yaitu observasi merupakan teknik pengumpulan data yang berfungsi dalam menunjang tujuan penelitian. Melakukan observasi memberikan kemudahan-kemudahan terutama untuk memperoleh data di lapangan. Melakukan secara langsung pengamatan di SMA Negeri 01 Kota Batu.

Wawancara yang dilakukan pada siswa SMA Negeri 01 Batu menggunakan cara bebas terpimpin, dengan alasan karena metode ini memberikan kemudahan pada peneliti dan tetap mengacu pada hal yang ditentukan sehingga pada saat proses wawancara yang dilakukan dapat berjalan dengan baik, tidak ada ketegangan dengan masalah penelitian. Sedangkan, wawancara pada guru PPKn dan kesiswaan, peneliti menggunakan wawancara semi terstruktur. Wawancara semi terstruktur dalam pelaksaannya lebih bebas.

Dokumen yang dapat membantu dalam pengumpulan data pada penelitian ini yang berkaitan dengan bukti fisik. Dalam hal ini, peneliti mengumpulkan data berupa dokumentasi,jurnal dan buku-buku mengenai informasi yang terkait dan foto-foto yang berkaitan dengan pendidikan karakter sebagai upaya meneguhkan kesadaran nasional siswa. Dokumentasi diambil secara langsung di SMA Negeri 01 Kota Batu, berupa foto atau gambar situasi sekolah dan beberapa kegiatan yang dilaksanakan di SMA Negeri 01 Kota Batu.

Teknik analisis data dalam penelitian ini menurut Miles dan Humberman, terdapat empat cara analisis data kualitatif, yaitu pengumpulan data, penyajian data dan penarikan kesimpulan. Adapun langkah yang dapat dilakukan adalah, pengumpulan data, penyajian data, dan penarikan kesimpulan atau verifikasi data.

Pemeriksaan keabsahan data dilaksanakan dengan teknik triangulasi metode. Triangulasi ini digunakan untuk menguji kredibilitas data yang dilakukan dengan cara membandingkan informasi atau data dengan cara yang berbeda. Contohnya, data yang diperoleh peneliti dengan cara wawancara kepada informan yang berbeda yaitu pihak kesiswaan, guru PPKn, dan siswa, lalu di cek dengan observasi melalui pengamatan-pengamatan dan dokumentasi agar mendapatkan kepastian dan kebenaran data mengenai penguatan pendidikan karakter sebagai upaya peneguhan kesadaran nasional siswa di SMA Negeri 01 Kota Batu. 


\section{HASIL DAN PEMBAHASAN}

Undang-Undang

Republik

Indonesia nomor: 20 tahun 2003 tentang

Sistem Pendidikan Nasional (UU

Sisdiknas) merumuskan fungsi dan tujuan pendidikan nasional yang harus digunakan dalam mengembangkan upaya pendidikan di Indonesia. Pasal 3 UU Sisdiknas menyebutkan, "Pendidikan nasional berfungsi mengembangkan dan membentuk watak serta peradaban bangsa yang bermartabat dalam rangka mencerdaskan kehidupan bangsa, bertujuan untuk berkembangnya potensi peserta didik agar menjadi manusia yang beriman dan bertakwa kepada Tuhan Yang Maha Esa, berakhlak mulia, sehat, berilmu, cakap, kreatif, mandiri, dan menjadi warga negara yang demokratis serta bertanggungjawab. berdasarkan hal tersebut, terdapat hasil penelitian yang telah dibahas sebagai berikut:

\section{Pelaksanaan Pendidikan Karakter Sebagai Upaya Peneguhan Kesadaran Nasional pada Siswa SMAN 01 Kota Batu}

Mengenai pelaksanaan pendidikan karakter di SMA Negeri 1 Kota Batu telah diupayakan melalui berbagai hal. Pentinya pendidikan karakter juga telah diakui oleh semua pihak, dalam pelaksanaannya juga turut dilaksanakan semua pihak tidak hanya oleh siswa tetapi juga guru sebagai suri tauladan dan pendorong siswa untuk memiliki karakter baik sesuai nilai-nilai karakter baik, yaitu religius, nasionalis, mandiri, gotong royong, dan integritas. Kelima nilai utama karakter tersebut telah terwujud melalui berbagai kegiatan. Seperti beberpa kegiatan ekstrakulikuler yaitu, pramuka, paskibraka, maupun kegiatan intrakulikuler seperti OSIS yang ada di SMA Negeri 01 Kota Batu.

Berdasarkan upaya yang telah dilakukan tersebut, terdapat pula penemuan yang relevan oleh Putri (2018) mengenai pengimplementasian nasionalisme, rasa nasionalismemerupakan bagianterpentingyang harus diimplementasikan dalam kehidupan sehari-hari. Sekolah merupakan salah satu lembaga yang dapat digunakan untuk menumbuhkan semangat nasionalisme kepada generasi muda. Salah satu kegiatan di sekolah yang mampu menumbuhkan rasa nasionalisme yaitu, upacara bendera hari senin, dimana kegiatan tersebut dijadikan solusi untuk memperkuat rasa nasionalisme dikalangan pelajar.

Pendidikan karakter penting didapat oleh siswa, para siswa juga menyadarai betapa pentinya memiliki karakter yang baik di era seperti saat ini, yang muncul berbagai pengaruh negatif dari berbagai hal. Sesuai dengan devinisi bahwa, karakter sebagai pola perilaku yang bersifat individual dan keadaan moral seseorang (Daryanto dan Suyatri, 2013). Terdapat pendapat pula yang menyebutkan bahwa jika sudah memiliki karakter yang baik, maka rasa kesadaran nasional itu akan ikut tumbuh dengan sendirinya. Karakter dimaknai sebagai cara berpikir dan berperilaku yang khas tiap individu untuk hidup dan bekerja sama, baik dalam lingkup keluarga, masyarakat, bangsa, dan negara. Pemberian pengarahan ataupun penanaman melalui pembelajaran dikelas, terutama pada mata pelajaran PPKn juga amat penting.

Berdasarkan temuan yang telah ada atau penelitian terdahulu dari Muqoyyidin (2017) terdapat kesamaan yaitu, dalam penerapan pendidikan karakter dilakukan secara menyeluruh atau hendaknya dilakukan melalui berbagai program sekolah. Melalui kegiatan belajar mengajar disekolah, melalui pengembangan budaya sekolah dilakukan pembiasaan dalam selruh kegiatan disekolah, adanya kegiatan ekstrakulikuler, termasuk pembinaan untuk pebiasaan diluar sekolah saat dilingkungan masyarakat.

Penemuan yang relevan mengenai penerapan pendidikan karakter oleh Maunah (2015) menyimpulkan bahwa, pengelolaan pendidikan karakter dapat dilakukan melalui strategi internal 
sekolah dan eksternal sekolah. Strategi internal sekolah dibagi menjad empat pilar, yakni kegiatan belajar mengajar dikelas, kegiatan keseharian dalam bentuk budaya sekolah (school culture), kegiatan pembiasaan (habituation), dan kegiatan ekstrakulikuler. Berkaitan dengan strategi eksternal luar sekolah, pendidikan karakter dapat dilakukan di luar sekolah seperti lingkungan keluarga dan masyarakat.

Menanamkan pendidikan karakter tidak bisa dilakukan seperti mentransfer ilmu pengetahuan atau mengajarkan sesuatu pelajaran kepada peserta didik. Pendidikan karakter perlu bimbingan, keteladanan, pembiasaan, atau pembudayaan serta ditunjang oleh iklim lingkungan yang kondusif, baik lingkungan keluarga, sekolah, dan masyarakat. Proses pembiasaan dan keteladanan melalui lingkungan yang kondusif ini kenyataannya tidak mudah (Hamid, 2012).

\section{Kendala pada Penerapan Pendidikan Karakter Sebagai Upaya Peneguhan Kesadaran Nasional Siswa SMAN 01 Kota Batu}

Sisi lain pengaruh dunia luar yang sangat besar terhadap kehidupan siswa juga dapat menjadi kendala. Jika disekolah telah ditanamkan pendidikan karakter yang baik dan diterapkan peraturan yang harus ditaati sehingga siswa memiliki karakter baik sesuai harapan sekolah, tetapi pihak sekolah tidak dapat mengontrol ketika siswa telah berada diluar lingkungan sekolah yang dalam hal ini dapat menjadi pengaruh tidak baik terhadap siswa. Tidak hanya pengaruh dari sesama manusia tetapi juga pengaruh sosial media yang berkembang begitu pesat. Siswa dapat melihat banyak hal dari belahan dunia manapun, ini merupakan kendala dan tugas besar pihak sekolah untuk menanamkan dan mengajarkan siswa agar tidak mudah terpengaruh hal negatif apapun, sehingga dapat menyaring segala hal yang diketahui.
Contonya seperti ketika disekolah diajarkan kejujuran, maka diluar sekolah siswa harus selalu memiliki kesadaran bertindak jujur terhadap siapapun, walaupun secara nyata mereka sering pula melihat ketidakjujuran dari orang lain. Kesadaran siswa dimulai dari mata secara fisik (eye of flesh), yang langsung melihat atau mengalami, sehingga menjadi pengalaman yang diteruskan ke ranah piker dan menjadi mata piker (eye of mind) bagi setiap tindakan. Dari pengalaman menjadi pemikiran dan bertindak. Dari tindakantindakannya pasti timbul reaksi. Lepas dari positif ataupun negative tindakan tersebut, maka akan menjadi bahan renungan dan sebagai pertimbangan dalam berbagai hal. Sehingga nilai-nilai yang telah diterima dari proses penanaman nilai-nilai bela Negara tersebut menjadi kesadaran mata hati (eye of contemplation) yang senantiasa melekat dalam jiwa siswa ( Ylianto Hadi, 2014)

Sejalan dengan hal tersebut pada penemuan oleh Zulhijrah (2015) yaitu, evaluasi bertujuan untuk mengembangkan dan meningkatkan kualitas program pembinaan pendidikan karakter sesuai dengan perencanaan yang telah ditetapkan. Terkait hal ini, bentuk evaluasi dilakukan oleh SMA Negeri 01 Kota Batu dilakukan dengan beberapa cara antara lain: setiap siswa memiliki buku tata tettib dengan penilaian skor sesuai jenis pelanggaran yang dilakukan oleh peserta didik. Selain itu, bentuk evaluasi adanya koordinasi antara guru dan pengelola tatib. Serta adanya kerjasama antara pihak sekolah dengan BNN dan Kepolisian Kota Batu.

Berdasarkan hal tersebut, pelaksanaan upaya-upaya yang diterapkan, seperti kegiatan-kegiatan juga tidak pernah menghadapi masalah atau kendala. Karena SMA Negeri 01 Kota Batu selalu mendukung berbagai kegaiatan yang konteksnya positif bagi siswa. Apapun kegiatannya, entah yang diadakan oleh 
pihak sekolah ataupun diadakan oleh siswa. Sehingga siswa tidak hanya unggul pada kemampuan akademik tetapi juga non akademik, serta dari kegiatan-kegiatan tersebut pula diharapkan membawa dampak dan pengaruh positif terhadap siswa. Upaya yang dilakukan guru, terutama pada pembelajaran PPKn di SMA Negeri 01 Kota Batu terbilang dapat diterima oleh siswa. Hasil temuan memperlihatkan bahwa, siswa juga tidak menghadapi kendala atau penghambat bagi siswa untuk menyampaikan pendapat dan dialogdialog yang dilakukan untuk meneguhkan kesadaran nasional siswa sangat berperan banyak dalam pembentukan karakter siswa.

\section{Revitalisasi Pendidikan Karakter Sebagai Upaya Peneguhan Kesadaran Nasional pada Siswa SMAN 01 Kota Batu}

Tentunya jika melihat dari segi merevitalisasi untuk mengangkat betapa pentingnya pendidikan karakter sebagai upaya peneguhan kesadaran nasional, SMA Negeri 01 Kota Batu selalu mengupdate berbagai kegiatan yang sekiranya penting melatih diri siswa dan memunculkan kesadaran positif dalam diri siswa. Penelitian terdahulu yang menyebutkan pula bahwa, revitalisasi pendidikan karakter harus dilakukan secara menyeluruh, karena dengan berkembangnya berbagai isu-isu, Indonesia dianggap belum mampu membangun karakter bangsa. Pendekatan menyeluruh dalam pendidikan karakter adalah cara pandangbahwa untuk membangun karakter perlu dikembangkan sebuah sistem pendidikan karakter yang memungkinkan seluruh unsur-unsur karakter (ngerti, ngroso, dan nglakoni) atau unsur-unsur (moral knowing, moral feeling, dan moral action) atau keseimbangan pikir, dzikir, ikhtiar dapat dipraktekkan dalam kehidupan dan pembelajaran nilai dan karakter di institusi pendidikan.

Pendidikan karakter dapat terlaksana dengan baik apabila lembaga pendidikan dapat membenahi kondisi dan mutunya yang berhubungan langsung dengan fungsi dan peran lembaga pendidikan itu sendiri. Herbert Spenser menjelaskan bahwa "education has for its object the formation ofcharacter" pendidikan bertujuan untuk membentuk karakter (Arsyad, 2011). Selain itu, terlaksananya pendidikan karakter memerlukan kesadaran, semangat, dan komitmen yang tinggi dan disertai dengan strategi yang tepat sehingga pendidikan karakter dapat berjalan efektif.

Menurut temuan Natasha (2012), keberhasilan pendidikan berkarakter sangat ditentukan oleh lembaga pendidikan yang berkarakter, ini tercermin dari karakter yang ada pada guru atau dosen, pemimpin pendidikan dan lingkungan lembaga pendidikan. Pemberdayaan perangkat lembaga pendidikan terutamapimpinanpendidikandanguruataudosen dengan memberikan kesempatan mengfungsikan dan mendinamisasikan penerapan falsafah bangsa kedalam pranata-pranata pendidikan secara terpadu dan berkelanjutan.

Berdasarkan temuan terdahulu oleh Iriany (2014), dampak dari melemahnya atau hilangnya jati diri bangsa dan pola perilaku masyarakat yang baru tersebut tidak sesuai dengan keadaan bangsa itu, maka akan melemahkan keadaan bangsa tersebut dalam berbagai bidang. Sehingga dapat dengan mudah bangsa itu dihancurkan atau dijajah oleh negara lain. Kaitan dengan hal tersebut, (2018) berpendapat bahwa, penanaman nilai-nilai nasionalisme diharapkan menjadi bekal masyarakat untuk tetap semangat dalam menjaga persatuan dan kesatuan bangsanya. Upaya peneguhan yang diterapkan di SMA Negeri 01 Kota Batu sehubungan dengan pendapat tersebut di atas, telah dilakukan dan didukung oleh seluruh pihak sekolah maupun siswa terbukti dari penyelenggaraan kegiatan selalu menginternalisasikan kesenian budaya Indonesia sebagai bentuk mengapresiasi, menjaga, dan melestarikan kekayaan budaya bangsa Indonesia. 
Tentunya jika melihat dari segi merevitalisasi untuk mengangkat betapa pentingnya pendidikan karakter sebagai upaya peneguhan kesadaran nasional, SMA Negeri 01 Kota Batu selalu mengupdate berbagai kegiatan yang sekiranya penting melatih diri siswa dan memunculkan kesadaran positif dalam diri siswa. Siswa dapat mengetahui dan menggali karakter dalam dirinya sendiri, sehingga mengetahui baik dan buruknya. Meneguhkan kesadaran nasional dalam diri siswa memang tidak mudah, tetapi SMA Negeri 01 Kota Batu selalu berusaha mengupayakan berbagai kegiatan tidak hanya pembelajaran dan sosialisasi tetapi juga praktek yang dioptimalkan melalui berbagai kegiatankegiatan, karena upaya seperti itu akan lebih mengena di dalam diri siswa dari pada hanya melalui pembelajaran ataupun sosialisasi. Konsisten dan keseimbangan SMA Negeri 01 Kota Batu yang diharapkan pendidikan karakter dapat ditanamkan dengan baik sebagai pula upaya peneguhan kesadaran nasional siswa SMA Negeri 01 Batu.

Kaitan dengan hal tersebut dari penemuan yang telah ada oleh Maftuh (2008), untuk mendukung upaya pembinaan nilai-nilai Pancasila dan nasionalisme di sekolah melalui pembelajaran PKn, maka perlu diupayakan pembelajaran PKn yang memiliki kekuatan (powerfull). Pembelajaran PKn akan memiliki kekuatan (powerfull) jika diajarkan secara: bermuatan nilai, bermakna, aktif, terpadu, mengundang kemampuan berfikir tingkat tinggi, demokratis, menyenangkan (joyful), efective, efisien, kreatif, melalui belajar dengan bekerja sama (cooperative learning), dan mengundang aktivitas sosial.

Penelitian oleh Muqoyyidin (2017) menyebutkan bahwa, Pelaksanaan pendidikan karakter dalam konteks makro kehidupan berbangsa dan bernegara Indonesia, merupakan komitmen seluruh sektor kehidupan, bukan hanya sektor pendidikan nasional. Keterlibatan aktif dari sektor-sektor pemerintahan lainnya, khususnya sektor keagamaan, kesejahteraan, pemerintahan, komunikasi dan informasi, kesehatan, hukum dan hak asasi manusia, serta pemuda dan olahraga juga sangat dimungkinkan. Dalam revitalisasi jati diri bangsa melalui pendidikan karakter, strategi mikro dalam pendidikan karakter, dapat dilakukan melalui keluarga, keluarga dapat berperan sebagi fondasi.

\section{SIMPULAN}

Pelaksaan pendidikan karakter di SMA Negeri 1 Kota Batu telah diupayakan melalui berbagai hal. Pentinya pendidikan karakter juga telah diakui oleh semua pihak, dalam pelaksanaannya juga turut dilaksanakan semua pihak tidak hanya oleh siswa tetapi juga guru sebagai suri tauladan dan pendorong siswa untuk memiliki karakter baik sesuai nilai-nilai karakter baik, yaitu religius, nasionalis, mandiri, gotong royong, dan integritas. Kendala yang dihadapi atau ditemukan jika dilihat dari segi pertentangannya, terdapat pertentangan antara yang diupayakan sekolah dengan yang terjadi secara nyata diluar sekolah atau di lingkungan pergaulan siswa. Revitalisasi atau penghidupan kembali mengenai pendidikan karakter sebagai upaya peneguhan kesadaran nasional di SMA Negeri 01 Kota Batu, berdasarakan hasil penelitian tidak ada upaya, peraturan maupun kegiatan yang dihidupkan kembali atau diangkat kembali setelah tidak dilaksanakan atau diperhatikan. SMA Negeri 01 Kota Batu merasa selalu menjalankan segala hal dengan teratur dan konsisten, tidak ada yang dikurangi maupun dihilangkan sejak adanya peraturan.

Sebaiknya dioptimalkan pula dalam kegiatan-kegiatan seperti memperingati hari-hari nasional. Melibatkan siswa dalam kegiatan yang berhubungan dengan kebangsaan akan semakin meneguhkan 
kesadaran nasional siswa.Melakukan pendekatan lebih mendalam dan terfokus kepada siswa yang dapat dilakukan oleh guru. Revitalisasi tersebut dilakukan agar prestasi dapat terus dikembangkan dan peneguhan rasa nasionalisme siswa dapat dilakukan dengan maksimal. Karena perlunya inovasi di era seperti saat ini.

\section{DAFTAR PUSTAKA}

Arsyad, Azhar. (2011). Strategi dan Implementasi Pendidikan Karakter Bangsa di Perguruan Tinggi. Makalah Ilmu Pendidikan disajikan pada ACIS ke-11. Dalam Yeni Asmara, (Online), https://yeni-asmara.blogspot.com, diakses 2 Januari 2019

Daryanto, \& Suyatri Darmiyatun. (2013). Implementasi Pendidikan Karakter di Sekolah. Yogyakarta: Gava Media.

Firmansyah, M Julnis \& Anwar, Ali. (2018). KPAI: Tawuran Pelajar 2018 Lebih Tinggi Dibanding Tahun Lalu. TEMPO,(online), diakses melalui (https://www.google.com/amp/s/ metro.tempo.co/amp1125876/kpaitawuran-pelajar-2018-lebih-tinggidibanding -tahun-lalu), diakses 2 Januari 2019.

Hadi, Yulianto. (2014). Dinamika Penanaman Nilai-Nilai Bela Negara Kadet Maguwo Dalam Perspektif Historis. Jurnal Pembangunan Pendidikan, 2 (2), 210-221.

Hamid, Edi Suandi. (2012). Peran Pendidikan Untuk Mengukuhkan Nasionalisme Dan Membangun Karakter Bangsa. Jurnal Pendidikan, 36 (76), 41-46.

Ilahi, Mohammad Takdir. (2014). Gagalnya Pendidikan Karakter (Analisi dan Solusi Pengendalian Karakter Emas Anak Didik). Yogyakarta: Ar-Ruzz Media.

Iriany, Ieke Sartika. (2014). Pendidikan Karakter Sebagai Upaya Revitalisasi Jati Diri Bangsa. Jurnal Pendidikan, 8 (1), 54-85.
Lestari, Eta Yuni. (2019). Menumbuhkan Kesadaran Nasionalisme Generasi Muda di Era Globalisasi Melalui Penerapan Nilai-Nilai Pancasila. Jurnal Ilmu Pendidikan, 1 (1), 20-27. Lestari, Sri Uji. (2018). Penanaman Nilai-Nilai Nasionalisme Dalam Pembelajaran Sejarah Lokal Perjuangan Rakyat Sukorejo Kelas IX di SMA Negeri 1 Sukorejo. Jurnal Pendidikan Sejarah Indonesia, 6 (2), 205-215.

Maftuh, Bunyamin. (2008). Internalisasi Nilai-Nilai Pancasila dan Nasionalisme Melalui Pendidikan Kewarganegaraan. Jurnal Ilmu Pendidikan, 2 (2), 134-144. Maunah, Binti. (2015). Implementasi Pendidikan Karakter Dalam Pembentukan Kepribadian Holistik Siswa. Jurnal Ilmu Pendidikan, 5 (1), 90-101.

Muqoyyidin, Andik Wahyun. (2017). Revitalisasi Pendidikan Karakter dalam Membangun Generasi Andal dan Berbudi Pekerti. Jurnal Ilmu Pendidikan, 1 (1), 1-20.

Natasha, Harum. (2012). Revitalisasi Lembaga Pendidikan Dalam Upaya Membangun Karakter Bangsa. Jurnal Pemikiran Islam, 37 (1), 89-93.

Putri, A Sintya Hapsari. (2018). Penanaman Nilai Nasionalisme Melalui Kegiatan Upacara Hari Senin Pada Siswa SMP Negeri 3 Sawit Kabupaten Boyolali Tahun Pelajaran 2017/2018. Skripsi Diterbitkan, (Online), diakses melalui (https://eprints.ums.ac.id), diakses 14 Agustus 2019.

Ramdhani, MuhammadAli.(2014). Lingkungan

Pendidikan Dalam Implementasi Pendidikan Karakter. Jurnal Pendidikan Universitas Garut, 8 (1), 28-37.

Saat, Sulaiman. (2015). Faktor-Faktor Determinan Dalam Pendidikan (Studi Tentang Makna Dan Kedudukannya Dalam Pendidikan). Jurnal AlTa'dib, 8 (2), 1-17. 
Setiawati, Nanda Ayu. (2017). Pendidikan Karakter Sebagai Pilar Pembentukan Karakter Bangsa. Jurnal Pembangunan Pendidikan, 1 (1), 348-352.

Sugiyono. (2015). Metode Penelitian Pendidikan (Pendekatan Kuantitatif, Kualitatif, dan R\&D). Bandung: CV. Alfabeta.

Sutrisno. (2016). Berbagai Pendekatan Dalam Pendidikan Nilai Dan Pendidikan Kewarganegaraan. Jurnal Dimensi Pendidikan Dan Pembelajaran, 5, 29-37.

Yaumi, Muhammad. (2015). Pendidikan Karakter: Landasan Pilar dan Implementasi. Jakarta: Prenadamedia Group.

Zulhijra. (2015). Implementasi Pendidikan Karakter di Sekolah (Studi Multi Kasus di SMA Negeri 01 Batu dan MA Negeri Kota Batu. Malang: Pascasarjana Pendidikan Agama Islam Universitas Islam Negeri Maulana Malik Ibrahim Malang. Tesis Diterbitka, (Online), (http://lib. unnes.ac.id/29550/1/1102413021. pdf\&ved $=$ ), diakses 6 Desember 2018. 